\title{
Strategic analysis of clinical pharmacy education in Saudi Arabia
}

\author{
Ahmad A Almeman \\ Pharmacology and Therapeutic Department, College of Medicine, Qassim, Qassim University \\ *For correspondence: Email: meman@qu.edu.sa, ahmadalmeman@gmail.com; Tel: +966-505393494 \\ Sent for review: 7 January 2020 \\ Revised accepted: 21 May 2020

\begin{abstract}
Purpose: To analyze the strategic position of clinical pharmacy education in Saudi Arabia and ensure that it meets the needs of the current industry in the country.

Methods: A comprehensive and structured analysis of strengths, weaknesses, opportunities, and threats (SWOT) was performed with more than 100 clinical pharmacists, academic staff, and students as participants. An internal factor evaluation (IFE), external factor evaluation (EFE), and SWOT matrix were conducted to compare the provisions of the current system with market needs.

Results: The analysis involved more than 40 academic staff members, 35 clinical pharmacists, 50 students, and several administrative staff members. The EFE and IFE were calculated as 2.06 and 2.2, respectively, and were lower than the accepted international standard. The internal and external analyses involved 37 and 20 items, respectively. Finally, a SWOT matrix was constructed to help for proposing the strategies. Several strategies were recommended to address eventual shortcomings.

Conclusion: The great paradigm shifts in the pharmaceutical market warrant an equal paradigm shift in clinical pharmacy education. More strategic data are needed to further analyze the market in the next five to ten years. Adopting the current educational modality to best match the needs of the pharmaceutical market is also essential.
\end{abstract}

Keywords: Clinical pharmacy, Education, SWOT analysis, Strategic planning

\begin{abstract}
This is an Open Access article that uses a fund-ing model which does not charge readers or their institutions for access and distributed under the terms of the Creative Commons Attribution License (http://creativecommons.org/licenses/by/4.0) and the Budapest Open Access Initiative (http://www.budapestopenaccessinitiative.org/read), which permit unrestricted use, distribution, and reproduction in any medium, provided the original work is properly credited.
\end{abstract}

Tropical Journal of Pharmaceutical Research is indexed by Science Citation Index (SciSearch), Scopus, International Pharmaceutical Abstract, Chemical Abstracts, Embase, Index Copernicus, EBSCO, African Index Medicus, JournalSeek, Journal Citation Reports/Science Edition, Directory of Open Access Journals (DOAJ), African Journal Online, Bioline International, Open-J-Gate and Pharmacy Abstracts

\section{INTRODUCTION}

There are almost 30 pharmacy schools in the Kingdom of Saudi Arabia (KSA), all equally eager to align with global standards in clinical pharmacy education and cope with the country's expanding pharmaceutical industry [1,2]. These schools must adopt a holistic approach to comprehensive development, enhance their role in development, and improve their products and services in line with superior standards of higher education in the KSA [3,4]. Most schools have prepared their ten-year strategic plans (20162026) based on several scientific methodologies, resulting in significant variances between them and possible asymmetries with the needs of the clinical pharmacy industry $[3,5]$.

The KSA's pharmaceutical sector has grown rapidly, partly because of government efforts by the Ministry of Health, job availability, grants for higher education, and local pharmacy training 
$[6,7]$. Notably, the pharmaceutical sector is the major provider of medicine in the KSA. It has also started exporting medicines to the global market following the recent increase in the number of manufacturers and establishment of research-based firms in the country. Thus, the sector shows great promise for developing the KSA economy [8]. Therefore, educational research is needed in the pharmacy field to improve opportunities for the industry's future development [9].

To better match clinical pharmacy education with the changing needs of the pharmaceutical industry, a strategic analysis is needed to explore related opportunities and avoid threats, as well as to harness associated strengths and mitigate weaknesses. In other words, a Strengths, Weaknesses, Opportunities, and Threats (SWOT) analysis of current pharmaceutical education is essential to understand how to tailor it to suit industry needs. However, a nonregulated SWOT analysis would add few quantitative measurements and a simple or traditional SWOT analysis might not be beneficial for healthcare institutions [10,11]. In this case, a comprehensive, model-based, and structural SWOT analysis may illuminate how best to modify clinical pharmaceutical services in the KSA [12]. This type of SWOT analysis addresses several factors (e.g., stakeholders, resources, and trends) and is connected to several matrices, including an internal factor evaluation (IFE), an external factor evaluation (EFE), and a Political, Economic, Social, Technological, Legal, and Environmental (PESTLE) analysis [10]. Therefore, this study asks: What is the strategic status of pharmacy education in the KSA? To respond to this question, a comprehensive SWOT model was employed.

\section{METHODS}

In this study, the strategic planning process began with a comprehensive analysis of internal and external audits. Specifically, a SWOT analysis was performed based on stakeholders, contextual factors, and resources [10,12]. Next, strategies were established, evaluated, and selected by constructing specific qualitative and quantitative matrices. The participants were Consultant Pharmacists, Associate Professors/Professors of Clinical Pharmacy, Associate Professors/Professors of Pharmacy Practice, Associate Professors/Professors of Pharmaceutics, or Student Interns who were primarily involved in pharmacy education. More than 100 clinical pharmacists, academic staff, and students (only final-year interns) participated in this analysis. All participants were carefully selected based on their expertise in either clinical pharmacy education or the clinical pharmacy profession. Several students from different universities were asked to agree/disagree with the established items.

Participants were first requested to conduct the traditionally structured SWOT analysis in groups. Unlike an open, unstructured SWOT analysis, this type focused on the following major domains: stakeholders, resources, trends, and finances. The analysis resulted in a list of items. Participants were then asked to score and assign a weight to each item. In the case of disagreement, participants voted to reach consensus. The mean ranks and weights of the items were recorded. The analysis was divided into three sections based on the input, matching, and decision stages.

In the input stage, two matrices, namely IFE and EFE, were constructed using information collected from the SWOT analysis. The average weights and scores were considered based on participants' judgments. For the IFE matrix, major weaknesses were ranked 1 , minor weaknesses 2 , minor strengths 3 , and major strengths 4 . For the EFE matrix, ranks indicated how effectively clinical pharmacy education deals with the provided factor $(1=$ poor and $4=$ superior). The weighted scores in both matrices were equal to 1.

The matching stage involved combining the internal and external factors using a tool called SWOT matrix. Theoretically, internal factors should be able to control the stress induced by external factors. Therefore, the strengths were used to gain opportunities (S-O) and avoid threats (S-T). On the other hand, weaknesses were matched with opportunities (W-O) and threats $(\mathrm{W}-\mathrm{T})$ to enable better advance planning.

Significant effort and attention were given to the decision stage of the strategy formulation framework because matching external and internal critical success factors is key to the effective generation of feasible alternative strategies. Therefore, the IFE and EFE matrices and a SWOT matrix were used to formulate several strategies to solve or improve the analysis results.

\section{RESULTS}

The analysis involved more than 40 academic staff members, 35 clinical pharmacists, 50 students, and several administrative staff members. Table 1, Table 2 and Table 3, and 4 present the results of the SWOT analysis. Table 
1 shows the IFE matrix for strengths, Table 2 shows the IFE matrix for weaknesses, Table 3 shows the EFE matrix for opportunities, and Table 4 shows the EFvE matrix for strengths.

The IFE and EFE matrices were calculated as 2.06 and 2.2 , respectively. The internal analysis involved 37 items, including 15 strengths and 22 weaknesses. The external analysis involved 20 items, including 11 opportunities and 9 threats. Tables 5, 6, 7, and 8 show the SWOT matrices and several recommended strategies that were formulated based on the S-T, W-O, W-T, and SO matchings, respectively.

Table 1: IFE matrix for clinical pharmacy education - Strengths

\begin{tabular}{clccc}
\hline S/no. & Strength & $\begin{array}{c}\text { Weight } \\
\mathbf{0 - 1}\end{array}$ & $\begin{array}{c}\text { Rank } \\
\mathbf{1 - 4}\end{array}$ & $\begin{array}{c}\text { Weighted } \\
\text { score }\end{array}$ \\
\hline 1 & Experienced pharmacy staff & 0.03 & 4 & 0.12 \\
2 & Continuous participation in local and international activities & 0.03 & 3 & 0.09 \\
3 & Good academic communication levels (staff, students, & 0.03 & 4 & 0.12 \\
& administration) & 0.02 & 3 & 0.06 \\
4 & Students are trained well to solve academic issues & 0.03 & 3 & 0.09 \\
5 & Available electronic gate services for students & 0.03 & 4 & 0.12 \\
7 & Structured plans for accreditation & 0.02 & 4 & 0.08 \\
8 & Exposure to a variety of education modalities & 0.02 & 3 & 0.06 \\
9 & Access to scientific journals & 0.02 & 4 & 0.08 \\
10 & Reasonable lab preparation with continuous upgrades & 0.08 & 3 & 0.24 \\
11 & Most staff participate in school system development & 0.019 & 4 & 0.076 \\
12 & Most staff are aware of modern technology for research and & 0.01 & 3 & 0.03 \\
13 & communication & 0.02 & 4 & 0.08 \\
14 & Modern documentation system available & 0.025 & 4 & 0.1 \\
15 & Deanship orientation \& support for creating and conducting unique & 0.017 & 3 & 0.051 \\
\hline
\end{tabular}

IFE=Internal Factor Evaluation

Table 2: IFE matrix for clinical pharmacy education - Weaknesses

\begin{tabular}{|c|c|c|c|c|}
\hline S/no. & Weakness & Weight & Rank & $\begin{array}{l}\text { Weighted } \\
\text { Score }\end{array}$ \\
\hline 1 & No placement and career counseling facility in the school & 0.02 & 2 & 0.04 \\
\hline 2 & Lack of marketing strategies & 0.019 & 1 & 0.019 \\
\hline 3 & $\begin{array}{l}\text { Lack of strategies to enhance practical skills for acceptance of } \\
\text { pharmacists by other organizations }\end{array}$ & 0.019 & 1 & 0.019 \\
\hline 4 & Inadequate clinical research advisors & 0.019 & 1 & 0.019 \\
\hline 5 & No research facilities are available in the school & 0.019 & 1 & 0.019 \\
\hline 6 & Lack of clinically oriented pharmacy programs & 0.019 & 1 & 0.019 \\
\hline 7 & Limited clinical postgraduate and $\mathrm{PhD}$ programs & 0.03 & 1 & 0.03 \\
\hline 8 & $\begin{array}{l}\text { Minimal clinical research collaboration with national/international } \\
\text { organizations }\end{array}$ & 0.026 & 1 & 0.026 \\
\hline 9 & Independent budget for clinical departments & 0.022 & 1 & 0.022 \\
\hline 10 & No/inactive drug information center (DIC) & 0.02 & 1 & 0.02 \\
\hline 11 & Minimal drug and disease-related software & 0.01 & 2 & 0.02 \\
\hline 12 & No university hospital near the school for students' visits and training & 0.029 & 1 & 0.029 \\
\hline 13 & No first aid facility in the school & 0.01 & 2 & 0.02 \\
\hline 14 & Communication gap between academic \& clinical staff & 0.05 & 1 & 0.05 \\
\hline 15 & Students' weak English language proficiency & 0.02 & 1 & 0.02 \\
\hline 16 & Students have insufficient information about clinical pharmacy & 0.03 & 1 & 0.03 \\
\hline 17 & $\begin{array}{l}\text { Inadequate experience of staff to formulate questions and scenarios } \\
\text { related to clinical pharmacy }\end{array}$ & 0.03 & 2 & 0.06 \\
\hline 18 & $\begin{array}{l}\text { High academic load leading to limited time for extra-curricular } \\
\text { activities, research, and interaction with faculty members }\end{array}$ & 0.03 & 1 & 0.03 \\
\hline 19 & Absence of good total quality management (TQM) process & 0.035 & 1 & 0.035 \\
\hline 20 & Lack of pharmacy-managed clinics at the training site & 0.099 & 1 & 0.099 \\
\hline 21 & Inadequate training tools & 0.021 & 1 & 0.021 \\
\hline 22 & Limited translation of basic sciences into clinical applications & 0.022 & 1 & 0.022 \\
\hline Total & & 1 & --- & 2.066 \\
\hline
\end{tabular}

IFE=Internal Factor Evaluation 
Table 3: EFE matrix for clinical pharmacy education - Opportunities

\begin{tabular}{|c|c|c|c|c|}
\hline S/no. & Opportunity & $\begin{array}{l}\text { Weight } \\
0-1\end{array}$ & $\begin{array}{c}\text { Rank } \\
1-4\end{array}$ & $\begin{array}{l}\text { Weighted } \\
\text { Score }\end{array}$ \\
\hline 1 & $\begin{array}{l}\text { Recruiting qualified clinical pharmacists and clinical academicians } \\
\text { worldwide }\end{array}$ & 0.04 & 3 & 0.12 \\
\hline 2 & $\begin{array}{l}\text { Arranging interaction programs with other featured universities in } \\
\text { clinical pharmacy }\end{array}$ & 0.04 & 4 & 0.16 \\
\hline 3 & $\begin{array}{l}\text { Improvement of faculty/staff clinical skills through various workshops } \\
\text { and trainings }\end{array}$ & 0.04 & 3 & 0.12 \\
\hline 4 & $\begin{array}{l}\text { Utilization of advanced educational tools \& techniques used by top- } \\
\text { ranked universities }\end{array}$ & 0.04 & 4 & 0.16 \\
\hline \multirow[t]{2}{*}{5} & $\begin{array}{l}\text { Collaboration and creation of memoranda of understanding (MOUs) } \\
\text { with pharmaceutical industries }\end{array}$ & & & \\
\hline & $\begin{array}{l}\text { - Clinical research organization } \\
\text { - Research and development institutes } \\
\text { - Centers of excellence in clinical pharmacy } \\
\text { - Highly specialized tertiary hospitals }\end{array}$ & 0.04 & 4 & 0.16 \\
\hline 6 & $\begin{array}{l}\text { Obtaining various instruments and laboratory machinery to initiate } \\
\text { diverse clinical research activities }\end{array}$ & 0.03 & 2 & 0.06 \\
\hline 7 & $\begin{array}{l}\text { Conducting organized clinical research in collaboration with other } \\
\text { institutions }\end{array}$ & 0.02 & 2 & 0.04 \\
\hline 8 & $\begin{array}{l}\text { Conducting annual meetings and conferences at the national and } \\
\text { international levels in clinical pharmacy and therapeutics }\end{array}$ & 0.02 & 2 & 0.04 \\
\hline \multirow{2}{*}{$\begin{array}{c}9 \\
10\end{array}$} & Establishing more pharmacy-managed clinics & 0.03 & 3 & 0.09 \\
\hline & $\begin{array}{l}\text { Improving students' knowledge and skills by involving them in } \\
\text { seminars, workshops, \& symposia offered by the Ministry of Health \& } \\
\text { other organizations }\end{array}$ & 0.03 & 2 & 0.06 \\
\hline 11 & Utilizing new interactive learning tools and facilities & 0.03 & 4 & 0.12 \\
\hline
\end{tabular}

EFE=External Factor Evaluation

Table 4: EFE matrix for clinical pharmacy education - Threats

\begin{tabular}{|c|c|c|c|c|}
\hline S/no. & Threat & $\begin{array}{l}\text { Weight } \\
0-1\end{array}$ & $\begin{array}{c}\text { Rank } \\
1-4\end{array}$ & Weighted Score \\
\hline 1 & $\begin{array}{l}\text { Risk of high turnover of experienced } \\
\text { staff }\end{array}$ & 0.03 & 2 & 0.06 \\
\hline 2 & $\begin{array}{l}\text { Competition with graduates of private } \\
\text { schools for job opportunities, } \\
\text { especially because of the ease of both } \\
\text { enrolment \& a high graduation GPA }\end{array}$ & 0.031 & 2 & 0.062 \\
\hline 3 & $\begin{array}{l}\text { Reduced job opportunities with the } \\
\text { government }\end{array}$ & 0.15 & 1 & 0.15 \\
\hline 4 & $\begin{array}{l}\text { Competition with other regional and } \\
\text { national pharmacy schools }\end{array}$ & 0.049 & 4 & 0.196 \\
\hline 5 & $\begin{array}{l}\text { Talent drain of outstanding } \\
\text { pharmacists to external centers in } \\
\text { overseas universities }\end{array}$ & 0.02 & 3 & 0.06 \\
\hline 6 & $\begin{array}{l}\text { Resistance from healthcare and non- } \\
\text { healthcare institutions for training } \\
\text { students }\end{array}$ & 0.03 & 4 & 0.12 \\
\hline 7 & $\begin{array}{l}\text { Resistance from other professionals in } \\
\text { the healthcare team, such as } \\
\text { physicians, to the role of clinical } \\
\text { pharmacists in clinical decision- } \\
\text { making }\end{array}$ & 0.03 & 4 & 0.12 \\
\hline 8 & $\begin{array}{l}\text { Paradigm shift from clinical pharmacy } \\
\text { to different pharmacy fields }\end{array}$ & 0.15 & 1 & 0.15 \\
\hline 9 & $\begin{array}{l}\text { Occupation of clinical pharmacy jobs } \\
\text { with non-clinical pharmacists }\end{array}$ & 0.15 & 1 & 0.15 \\
\hline Total & & 1 & - & 2.2 \\
\hline
\end{tabular}

$E F E=E x t e r n a l$ Factor Evaluation 
Table 5: SWOT matrix - S-T strategies

\begin{tabular}{|c|c|c|}
\hline $\bar{s}$ & $\bar{T}$ & Strategy \\
\hline $\begin{array}{l}\text { - Good academic } \\
\text { communication levels (staff, } \\
\text { students, administration) } \\
\text { - Presence of unique sub- } \\
\text { specialties }\end{array}$ & $\begin{array}{l}\text { Risk of high turnover of experienced } \\
\text { staff } \\
\text { - Interactive programs with other } \\
\text { featured universities/schools/institutes } \\
\text { of clinical pharmacy to upgrade } \\
\text { teaching and research environment } \\
\text { and prevent staff leakage }\end{array}$ & $\begin{array}{l}\text { Develop positive academic } \\
\text { communication and interaction between } \\
\text { faculty and students }\end{array}$ \\
\hline $\begin{array}{l}\text { - Students are well trained to } \\
\text { solve their academic issues } \\
\text { - Well-exposed to different } \\
\text { educational modalities } \\
\text { - Experienced pharmacy staff }\end{array}$ & $\begin{array}{l}\text { Resistance from other professionals in } \\
\text { the healthcare team, like physicians, to } \\
\text { the role of clinical pharmacists in } \\
\text { clinical decision-making }\end{array}$ & $\begin{array}{l}\text { Design well-structured systems like team- } \\
\text { based learning (TBL), problem-based } \\
\text { learning (PBL), or active learning to help } \\
\text { students develop their clinical skills and } \\
\text { knowledge in order to be easily } \\
\text { accommodated by the healthcare system }\end{array}$ \\
\hline $\begin{array}{l}\text { - Well-oriented to the } \\
\text { integrated system }\end{array}$ & $\begin{array}{l}\text { - Competition with other regional and } \\
\text { national pharmacy schools } \\
\text { - Competition with graduates of private } \\
\text { schools for job opportunities, especially } \\
\text { because of the ease of both enrolment } \\
\text { \& a high graduation GPA }\end{array}$ & $\begin{array}{l}\text { Develop a focused and accurate strategy } \\
\text { by constituting different committees } \\
\text { regarding academic and research plans } \\
\text { to attract students with high GPAs and } \\
\text { improve the employee turnover rate } \\
\text { - Arrange workshops, seminars, and } \\
\text { motivational classes with high-quality } \\
\text { departments to improve staff experience } \\
\text { regarding integrated systems and } \\
\text { training, and develop a suitable } \\
\text { environment for teaching and learning } \\
\text { outcomes }\end{array}$ \\
\hline $\begin{array}{l}\text { - Structured plans for } \\
\text { national/international } \\
\text { accreditation }\end{array}$ & $\begin{array}{l}\text { - Lack of marketing strategies } \\
\text { - Inadequate clinical research advisors } \\
\text { - Lack of clinically-oriented pharmacy } \\
\text { programs } \\
\text { - Minimal clinical research collaboration } \\
\text { with national/international organizations }\end{array}$ & $\begin{array}{l}\text { Construct working groups with adequate } \\
\text { facilities and job stability, and assign } \\
\text { them responsibility to develop a systemic } \\
\text { approach to the national and international } \\
\text { accreditation of the institution }\end{array}$ \\
\hline
\end{tabular}

SWOT=Strengths, Weaknesses, Opportunities, and Threats; S-T=Strengths-Threats matching

Table 6: SWOT matrix - W-T strategies

\begin{tabular}{|c|c|c|}
\hline $\mathbf{W}$ & $\bar{T}$ & Strategy \\
\hline $\begin{array}{l}\text { Lack of clinically oriented } \\
\text { pharmacy training and } \\
\text { workshops in the school }\end{array}$ & 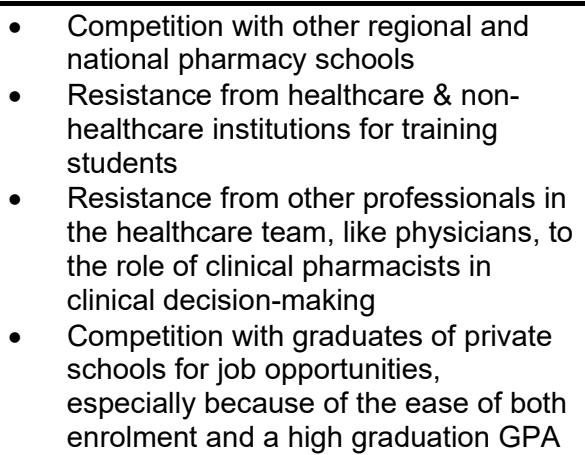 & $\begin{array}{l}\text { - Start clinically oriented training programs to } \\
\text { enhance students' clinical skills so that they know } \\
\text { their responsibility in healthcare settings and can } \\
\text { help make clinical decisions }\end{array}$ \\
\hline $\begin{array}{l}\text { - No postgraduate and } \\
\text { PhD programs }\end{array}$ & $\begin{array}{l}\text { Risk of high turnover of experienced } \\
\text { staff } \\
\text { Competition with other regional and } \\
\text { national pharmacy schools } \\
\text { Attraction of outstanding researchers } \\
\text { by external research centers in other } \\
\text { universities }\end{array}$ & $\begin{array}{l}\text { Establish a standing committee for master's and } \\
\text { PhD programs to coordinate mechanisms and } \\
\text { secure necessary funding and resource } \\
\text { commitments, organize primary logistics based } \\
\text { on the requirements of the university and school, } \\
\text { and develop appropriate mode of assessment } \\
\text { and outcome evaluation }\end{array}$ \\
\hline
\end{tabular}

SWOT = Strengths, Weaknesses, Opportunities, and Threats; WT = Weaknesses-Threats matching 
Table 7: SWOT matrix - W-O strategies

\begin{tabular}{|c|c|c|c|}
\hline & W & 0 & Strategy \\
\hline & $\begin{array}{l}\text { Lack of strategies for } \\
\text { enhancing practical } \\
\text { skills for acceptability } \\
\text { of clinical pharmacists } \\
\text { by other organizations }\end{array}$ & $\begin{array}{l}\text { - Collaboration in and creation of } \\
\text { memoranda of understanding } \\
\text { (MOUs) with all clinical } \\
\text { pharmacy service providers } \\
\text { - } \quad \text { Arranging interactive programs } \\
\text { with other featured universities } \\
\text { in clinical pharmacy } \\
\text { - Improvement of faculty/staff } \\
\text { clinical skills through various } \\
\text { workshops and trainings } \\
\text { - Utilization of advanced } \\
\text { educational tools and } \\
\text { techniques used by top-ranked } \\
\text { universities } \\
\text { - Improving students' knowledge } \\
\text { and skills by involving them in } \\
\text { seminars, workshops, and } \\
\text { symposia offered by the Ministry } \\
\text { of Health and other } \\
\text { organizations }\end{array}$ & $\begin{array}{l}\text { - Seek collaboration and MOUs with } \\
\text { premier institutions, hospitals, and } \\
\text { pharmaceutical industries } \\
\text { - Organize various interactive programs viz. } \\
\text { guest lectures with eminent professors, } \\
\text { scientists, and clinical professionals } \\
\text { - Set up a committee comprising faculty } \\
\text { and students, who will be primarily } \\
\text { responsible for organizing pharmacy } \\
\text { programs (conferences, workshops, } \\
\text { seminars, symposia, etc.) within the } \\
\text { school and interaction with other featured } \\
\text { universities in clinical pharmacy } \\
\text { - Make it mandatory to organize workshops, } \\
\text { seminars, and training programs with a } \\
\text { focus on clinical pharmacy } \\
\text { - Encourage the committee (for the } \\
\text { organization of pharmacy programs) to } \\
\text { utilize advanced educational tools and } \\
\text { techniques used by top-ranked } \\
\text { universities to organize pharmacy } \\
\text { programs } \\
\text { - Set up a team of students in concert with } \\
\text { teaching staff to organize conferences, } \\
\text { seminars, workshops, and training } \\
\text { sessions once or twice in an academic } \\
\text { calendar }\end{array}$ \\
\hline & $\begin{array}{l}\text { Lack of marketing } \\
\text { strategies }\end{array}$ & $\begin{array}{l}\text { - Lead the market by producing } \\
\text { highly qualified and skilled } \\
\text { clinical pharmacists who satisfy } \\
\text { the current needs of the KSA } \\
\text { - Utilization of media (audio, } \\
\text { video, and newspapers) to } \\
\text { promote the pharmacy } \\
\text { profession and pharmacist's } \\
\text { role in the community }\end{array}$ & $\begin{array}{l}\text { - Plan and activate a marketing strategy } \\
\text { after studying the needs of customers } \\
\text { such as employers, the community, and } \\
\text { students } \\
\text { - Amplify the marketing strategy through the } \\
\text { use of different media such as print, } \\
\text { electronic, and news services }\end{array}$ \\
\hline & $\begin{array}{l}\text { No university hospital } \\
\text { for students for } \\
\text { practice and training }\end{array}$ & $\begin{array}{l}\text { Improvement of faculty/staff } \\
\text { clinical skills through various } \\
\text { workshops and trainings }\end{array}$ & $\begin{array}{l}\text { - Participate in workshops and training } \\
\text { programs to prepare students for medical } \\
\text { emergencies and train them to administer } \\
\text { first aid } \\
\text { - Interact with relevant authorities of the } \\
\text { university and put forth a demand for } \\
\text { primary healthcare (with physicians during } \\
\text { school hours) at the institution's premises }\end{array}$ \\
\hline & $\begin{array}{l}\text { No drug information } \\
\text { center (DIC) }\end{array}$ & $\begin{array}{l}\text { - Collaboration with external fund- } \\
\text { providing organizations to } \\
\text { establish promising centers } \\
\text { such as pharmacogenetics }\end{array}$ & $\begin{array}{l}\text { - Constitute a committee comprising the } \\
\text { heads of the clinical and pharmacy } \\
\text { practice departments to develop a } \\
\text { detailed plan and budget to establish a } \\
\text { state-of-the art drug information center } \\
\text { (DIC) in the institution. } \\
\text { - Establish good connections with } \\
\text { pharmaceutical industries and hospitals } \\
\text { for signing MOUs and to attract funds }\end{array}$ \\
\hline & $\begin{array}{l}\text { Inadequate experience } \\
\text { of staff in formulating } \\
\text { questions and } \\
\text { scenarios related to } \\
\text { clinical pharmacy }\end{array}$ & $\begin{array}{l}\text { Utilization of advanced } \\
\text { educational tools and } \\
\text { techniques used by top-ranked } \\
\text { universities }\end{array}$ & $\begin{array}{l}\text { - Prepare a question bank that is frequently } \\
\text { updated with the aid of reputable } \\
\text { pharmacy schools } \\
\text { - Train clinical staff on best practices in } \\
\text { drafting exam questions }\end{array}$ \\
\hline
\end{tabular}

SWOT = Strengths, Weaknesses, Opportunities, and Threats; $W$-O = Weaknesses-Opportunities matching 
Table 8: SWOT matrix - S-O strategies

\begin{tabular}{|c|c|c|}
\hline 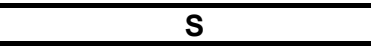 & 0 & Strategy \\
\hline $\begin{array}{l}\text { Structured plans for } \\
\text { national/international } \\
\text { accreditation }\end{array}$ & $\begin{array}{l}\text { Getting Pharm-D } \\
\text { programs recognized by } \\
\text { other distinguished } \\
\text { countries like the USA, } \\
\text { Canada, the UK, and } \\
\text { Australia }\end{array}$ & $\begin{array}{l}\text { Highlight Accreditation } \\
\text { Council for Pharmacy } \\
\text { Education-accredited } \\
\text { PharmD programs (NCAAA- } \\
\text { \& ACPE) to obtain } \\
\text { recognition from foreign } \\
\text { premier universities such as } \\
\text { those in the USA, Canada, } \\
\text { the UK, and Australia }\end{array}$ \\
\hline $\begin{array}{l}\text { Staff experience } \\
\text { regarding integrated } \\
\text { systems and training }\end{array}$ & $\begin{array}{l}\text { - Improving students' } \\
\text { knowledge and skills by } \\
\text { involving them in } \\
\text { seminars, workshops, } \\
\text { and symposia offered by } \\
\text { the Ministry of Health } \\
\text { and other organizations } \\
\text { Utilization of advanced } \\
\text { educational tools and } \\
\text { techniques used by top- } \\
\text { ranked universities }\end{array}$ & $\begin{array}{l}\text { - Take advantage of } \\
\text { experienced staff to improve } \\
\text { students' knowledge and } \\
\text { skills by encouraging them } \\
\text { to participate in various } \\
\text { seminars, workshops, and } \\
\text { symposia } \\
\text { Utilize advanced educational } \\
\text { tools used by top-ranked } \\
\text { universities to teach clinical } \\
\text { case studies to students } \\
\text { through teleconferences }\end{array}$ \\
\hline - Computer lab & $\begin{array}{l}\text { Publishing monthly } \\
\text { bulletin and research- } \\
\text { based journals } \\
\text { Utilizing new interactive } \\
\text { learning tools and } \\
\text { facilities under the } \\
\text { support of the university }\end{array}$ & $\begin{array}{l}\text { Motivate students and staff } \\
\text { to maximize the use of } \\
\text { computer lab facilities to } \\
\text { publish a monthly bulletin } \\
\text { and journals } \\
\text { Utilize interactive learning } \\
\text { tools to provide students and } \\
\text { staff with training and } \\
\text { lectures on clinical pharmacy } \\
\text { from eminent clinicians and } \\
\text { academicians }\end{array}$ \\
\hline $\begin{array}{l}\text { Availability of sufficient } \\
\text { training regarding } \\
\text { teaching and research }\end{array}$ & $\begin{array}{l}\text { - Collaboration in and } \\
\text { creation of MOUs with } \\
\text { pharmaceutical } \\
\text { industries }\end{array}$ & $\begin{array}{l}\text { - Collaborate with and create } \\
\text { MOUs with pharmaceutical } \\
\text { industries by highlighting the } \\
\text { teaching and research } \\
\text { credentials of teaching staff } \\
\text { to establish our institution as } \\
\text { a premier institute in clinical } \\
\text { pharmacy }\end{array}$ \\
\hline
\end{tabular}

SWOT=Strengths, Weaknesses, Opportunities, and Threats; S-O=Strengths-Opportunities matching

\section{DISCUSSION}

There are significant differences between pharmacy schools in the KSA, and each tends to apply the best-matched strategies based on its IFE and EFE matrices. As per standard theory of strategic planning processes, the average score for IFE and EFE matrices is approximately 2.5, with the highest score being 4 . In this study, the EFE matrix scored 2.2 (in the "poor" range) and the IFE matrix scored 2.06 (in the "minor weakness" range), indicating that clinical pharmacy education in the KSA is neither effective nor ineffective at exploiting opportunities or defending against threats. Likewise, many strengths are insufficient to address existing weaknesses and opportunities. This emphasizes balancing the cost invested with the required clinical pharmacy outcomes. Since clinical pharmacy is essential in the country, formulating evidence-based strategies is a crucial step in obtaining the best possible outcomes [13]. In the future, numerous educational strategies and modalities should be considered to keep up with the clinical pharmacy market [14]. Therefore, clinical pharmacy education should be improved by pursuing new institutional and educational strategies and focusing more on taking advantage of favorable opportunities in the country [15-17].

The pharmaceutical market in the KSA has demonstrated a growth trend in recent years [18]. Specifically, changing lifestyles due to urbanization and an increase in per capita income has escalated the demand for drugs, 
thereby creating a gap in clinical pharmacy education [6]. Moreover, because pharmaceutical products respond to basic needs, the industry is unlikely to decline in the future. Certainly, the KSA's growing population has expanded the health care market, creating more opportunities for pharmaceutical products and hospitals [19]. While the growth of this market offers an opportunity for clinical pharmacy in the KSA to expand [20], the number of clinical pharmacists in the country is currently growing at a low rate and may soon fall short of its required target $[21,22]$. This slow growth presents a great challenge for the fast-growing KSA market and, as shown in the matrices, may result in unmet needs. Another risk highlighted in the analysis is that clinical pharmacists with minimal clinical experience and low salaries may be redirected from clinical pharmacy to other pharmacy specialties [23].

Previously, the government played a substantial role in the growth of clinical pharmacy in the KSA. In particular, the government through the Ministry of Health facilitated the growth of clinical pharmacy by continuously evaluating the clinical pharmacy market and its needs, enhancing clinical pharmacy services in government hospitals, and approving more clinical pharmacy education programs $[6,24]$. However, with clinical pharmacy currently undergoing a privatization process in the KSA, the government now offers few jobs to clinical and hospital pharmacists, increasing the risk of job insecurity and sending passive messages about the changes needed regarding education [7]. Both points are addressed in the analysis and may be weighted more highly in the near future.

Currently, the strategic positioning and direction of clinical pharmacy and pharmaceutical care innovation is insufficient in the KSA. Here, the shortage of locally trained clinical pharmacists has been a major industry concern for decades $[6,7,23]$. Furthermore, clinical and pharmaceutical research is limited by the deficits of time, resources, and incentives. Regarding the latter factor, it is noteworthy that the few trained clinical pharmacist professionals in the KSA are able to migrate relatively easily to different regions in the Gulf Cooperation Council and Western countries after working in the KSA. Consequently, attracting and retaining the limited human capital available is financially and socially costly for the clinical pharmacy industry.

Finally, investment in clinical pharmacy research and development (R\&D) activities is quite expensive. High investment in R\&D does not produce expected levels of fast cash and revenue. Thus, investors tend to shy away from start-up activities in healthcare and related innovations [25]. As a result, there are very few registered clinical trials in the pharmaceutical field to match considering the massive expansion in the market overall, hindering job growth and education for clinical pharmacists [26].

\section{Limitations of the study}

The scarcity of data on the strategic pharmacy analysis is a major limitation of this study. Likewise, the expressive variability between schools should be considered when interpreting this analysis. The strategies are proposed based on the existing SWOT analysis, which was conducted by the participants in this study. Thus, strategies and suggestions may be amended by other schools based on their analysis.

\section{CONCLUSION}

The new era of clinical pharmacy education will likely witness educational institutions adopting new educational modalities to overcome the weaknesses and threats highlighted in this paper. Moreover, these institutions should invest strongly in their existing strengths and opportunities. Adopting education that matches the clinical pharmacy market will optimize the funding procedure and enable the adoption of a more cost-effective strategy.

\section{DECLARATIONS}

\section{Acknowledgement}

I would like to acknowledge all the participating professionals and students for their help in making this work a success.

\section{Conflict of interest}

No conflict of interest is associated with this work.

\section{Contribution of authors}

I declare that this work was done by the authors named in this article and all liabilities pertaining to claims relating to the content of this article will be borne by the author.

\section{Open Access}

This is an Open Access article that uses a funding model which does not charge readers or their institutions for access and distributed under the terms of the Creative Commons Attribution 
License (http://creativecommons.org/licenses/by/ 4.0) and the Budapest Open Access Initiative (http://www.budapestopenaccessinitiative.org/rea d), which permit unrestricted use, distribution, and reproduction in any medium, provided the original work is properly credited.

\section{REFERENCES}

1. Aljadhey $H$. Challenges facing advanced pharmacy practice experience in Saudi Arabia. Am J Pharm Educ 2013; 77(1): 19.

2. Alhamoudi A, Alnattah A. Pharmacy education in Saudi Arabia: The past, the present, and the future. Curr Pharm Teach Learn 2018; 10(1): 54-60.

3. Vlasses $P H$, Wadelin JW, Boyer JG, Travlos DV, Rouse MJ, Avery C. 2016 Annual Report of the Accreditation Council for Pharmacy Education. Am J Phar Educ 2017; 81(7): S9 [Cited 2019 April 2] Available from: https://www.ncbi.n/m.nih.gov/pubmed/29109573.

4. Zaitoun MF. Pharmacy education in Saudi Arabia: The current status. Curr Pharm Teach Learn 2018; 10(6): 673-674

5. National Commission for Academic Accreditation and Assessment. The National Commission for Academic Accreditation and Assessment, 2014 [Cited 2019 April 6] Available from: http://www.ncaaa.org.sa/en/Pages/default.aspx. Published Jan 2014

6. Ministry of Health. Ministry of Health Statistical Yearbook 1437H: Kingdom of Saudi Arabia [Cited 2019 April 1] Available from: https://www.moh.gov.sa/en/Ministry/Statistics/book/Doc uments/StatisticalBook-1436.pdf. Published Nov 2015

7. Al-Ruthia Y, Alsenaidy MA, Alrabiah HK, AlMuhaisen A, Alshehri M. The status of licensed pharmacy workforce in Saudi Arabia: A 2030 economic vision perspective. Hum Resour Health 2018; 16(1): 1-8.

8. Business Monitor International (BMI). Saudi Arabia pharmaceuticals \& healthcare report Q2 2018. [Cited 2019 Jan 19] Available from: https://www.marketresearch.com/OG-Analysisv3922/Future-Saudi-Arabia-Pharmaceuticals11462109/. Published Feb 2018.

9. Al-Asfour A, Khan SA. Workforce localization in the Kingdom of Saudi Arabia: Issues and challenges. Hum Resource Dev Int 2014; 17(2): 243-253.

10. van Wijngaarden JD, Scholten GR, van Wijk KP. Strategic analysis for health care organizations: The suitability of the SWOT analysis. Int J Health Plann Manage 2012; 27(1): 34-49.

11. Blayney DW. Strengths, weaknesses, opportunities, and threats. J Onc Pract 2008; 4(2): 53.
12. David FR. Strategic Management: Concepts and Cases. 13th ed. Upper Saddle River, NJ: Prentice Hall; 2010. $704 p$.

13. Francis J, Abraham S. Clinical pharmacists: Bridging the gap between patients and physicians. Saudi Pharm J 2014; 22(6): 600-602.

14. Almeman A, Alrobish S. Global achievements and challenges. In: Fathelrahman Al, Izham M, Alrasheedy $A$, Wertheimer $A$, editors. Pharmacy education in the twenty first century and beyond. London, UK: Academic Press; 2018: p. 200-249.

15. Alsultan MS, Mayet AY, Khurshid F, Al-Jedai AH. Hospital pharmacy practice in Saudi Arabia: Drug monitoring and patient education in the Riyadh region. Saudi Pharm J 2013; 21(4): 361-370.

16. Asiri YA. Emerging frontiers of pharmacy education in Saudi Arabia: The metamorphosis in the last fifty years. Saudi Pharm J 2011; 19(1): 1-8.

17. Aljadhey $H$, Asiri $Y$, Albogami $Y$, Spratto G, Alshehri M. Pharmacy education in Saudi Arabia: $A$ vision of the future. Saudi Pharm J 2016; 25(1): 88-92.

18. Schweitzer SO, Lu ZJ. Pharmaceutical Economics and Policy: Perspectives, Promises, and Problems. New York, NY: Oxford University Press; 2018. 432 p.

19. Alomi YA. New pharmacy model for vision 2030 in Saudi Arabia. J Pharm Pract Community Med 2017; 3(3): 194196.

20. Makeen HA. Clinical pharmacists as medication therapy experts in diabetic clinics in Saudi Arabia - Not just a perception but a need. Saudi Pharm J 2017; 25(6): 939943.

21. Bin Saleh G, Rezk NL, Laika L, Ali A, El-Metwally A. Pharmacist, the pharmaceutical industry and pharmacy education in Saudi Arabia: A questionnaire-based study. Saudi Pharm J 2015; 23(5): 573-580.

22. Al-Jedai A, Qaisi S, Al-Meman A. Pharmacy practice and the health care system in Saudi Arabia. Can J Hosp Pharm 2016; 69(3): 231-237.

23. Almeman A, Al-Jedai A. Pharmacy practice in the Kingdom of Saudi Arabia. In: Fathelrahman Al, Izham $M$, Wertheimer $A$, editors. Pharmacy practice in developing countries: Achievements and challenges. London, UK: Elsevier; 2016; p 171-197.

24. Ministry of Health, Saudi Arabia. Achievements. [Cited 2019 April 2] Available from: https://www.moh.gov.sa/Ministry/About/Documents/MO H-Report-2018.pdf. Published Dec 2017.

25. Blume-Kohout ME, Sood N. Market size and innovation: Effects of Medicare Part $D$ on pharmaceutical research and development. J Public Econ 2013; 97: 327-336.

26. Khanna I. Drug discovery in pharmaceutical industry: Productivity challenges and trends. Drug Discov Today 2012; 17(19-20): 1088-1102. 